\title{
Social qualities of time and space created in performing arts of West Java The implications for safeguarding living culture
}

\author{
WIM VAN ZANTEN
}

\begin{abstract}
Collective representations of "time" do not passively reflect time, but time and space are mediated by society. By our social practices, such as making music and dancing, we create time. Different cultural groups may experience and perceive time in different ways, and also within one cultural group the quality of time is not always experienced in the same way. Anthropological studies have shown that in each cultural group different perceptions of time co-exist. For instance, time generally tends to be perceived as both a linear flow and as repetitive. We should not confuse metaphysical and sociological arguments about time: time in music and other performing arts operates at the social and not at the metaphysical level. The essay discusses a variety of social qualities of time and space as it becomes manifest in some performing arts of West Java and the implications for their safeguarding.

KEYWORDS

Time and space, performing arts, West Java, Baduy, angklung, pantun story, safeguarding, UNESCO, intangible cultural heritage.
\end{abstract}

\section{INTRODUCTION}

Time is an essential part of human existence. However, the way we perceive and conceptualize the experience of time varies with cultural and historical contexts and with the position of individual members of a society (according to age, gender, position in the social structure). Hence different cultural groups may experience and perceive time in different ways and within one cultural group time may be experienced in a variety of ways. Time is created by human

WIM VAN ZANTEN was staff member at the Department of Cultural Anthropology and Development Sociology, Leiden University, from 1971-2007. He did fieldwork on music in Malawi (1969-1971, 2008) and Indonesia (1976-present). Most of his publications are on music of West Java, including the Baduy minority group, and some are about methodological issues in anthropology and ethnomusicology, including statistics for the social sciences. He has been involved in work concerning the 2003 UNESCO Convention for the safeguarding of the intangible cultural heritage since 2002 and published a few articles about this (see http:/ / wvzant27.home.xs4all.nl/). Wim van Zanten may be contacted at: wim.van.zanten@xs4all.nl.

(C) 2012 Faculty of Humanities, University of Indonesia 
beings, and making music is one of the means to experience and measure time.

Tenzer (2011) looks at the use of time in a general music-technical way. Tenzer's idea is "to think through the possibilities in a neutral and crosscultural way". He wants to classify music on the basis of "temporal structure rather than on culture, function, origin, psychology, cognition, meaning, or any other interpretive, subjective parameter" (Tenzer 2011:370).

I agree with Tenzer that the ideas of the anthropologist Alfred Gell (1992) are fundamental for understanding the concept of time and

although different philosophies or metaphysics or ritual practices of time are legion, it is quite another thing to say that individuals (let alone cultures) have fundamentally different experiences of time - except, of course, insofar as all people do as a function of their era, age, experience, capacities, backgrounds and so on [...] (Tenzer 2011: 369-370).

Although we should be sensitive to cultural and individual differences in perceiving and experiencing time, we should also have "an ambition to survey and compare, supra-culturally, species of musical temporality, and to envision relationships and connections not constrained by experience or culture" (Tenzer 2011: 384, footnote 1). Tenzer's approach is fundamentally different from the one I adopt in this essay.

I shall look at the variety of social qualities of time for mainly one group, the Sundanese in West Java. I shall conclude by looking at the implications of this analysis of time and space for the safeguarding of the intangible cultural heritage in the context of the 2003 UNESCO convention. This convention requires the active involvement of communities. Moreover, it is concerned with intangible cultural heritage that "communities, groups and, in some cases, individuals recognize as part of their cultural heritage" (UNESCO 2003: article 2). Therefore it is of great importance to know how different members of a community perceive and conceptualize experiences of time.

\section{NOTATION OF MUSIC AND TIME}

When I started writing on Sundanese cipher notation for music, I became interested in the concept of time. Musical notation is related to how "time" is perceived, that is, to the social quality of time. In my publications, I have been very critical about the cipher notation system (da-mi-na-ti-la) and modal theories of Machjar Angga Kusumadinata (Van Zanten 1986, 1989, 1995a, forthcoming a). ${ }^{1}$ In my 1986 article, I showed that none of the tuning models of the kacapi zither in tembang Sunda Cianjuran music corresponds with any of the models suggested by Jaap Kunst and Kusumadinata. ${ }^{2}$

1 When musicians consider two pieces of music to be different versions of "the same musical structure", they distinguish two different modes of a piece of music. See Van Zanten (1989: 131-134) for general remarks about Sundanese musical modes.

I showed that the pelog and sorog tone systems are fairly well represented by the following notes on a Western (equal-tempered) piano, from high to low: F - E - C - B flat - A - (F) for pelog and F - E - D - B flat - A - (F) for sorog. The saléndro tone system is according to 
Those models, still taught at the Bandung conservatory (STSI, Sekolah Tinggi Seni Indonesia), hamper the development of new music theory and communication with the world outside West Java. For instance, it is not possible to understand the (relative) cipher notation system of Kusumadinata (da-mi$n a-t i-l a$ ) without knowing his theories about Sundanese musical modes that are now considered to be very problematic by many scholars and Sundanese musicians. We need a new, thorough investigation of the Sundanese musical modes and it should be recognized that these modes are based on the structural ("scale") rather than on the melodic ("tune") function of the tones (Van Zanten, 1989: 133, forthcoming a). Simon Cook (1993) analysed the transformations of melodies between different tone systems (surupan) in Cianjuran music (pelog, sorog and saléndro), and in this way he made an excellent start in developing a new theory of Sundanese musical modes. ${ }^{3}$

When writing my article on Sundanese music notation (Van Zanten 1995a), I was challenged to think more thoroughly about the concept of "time" in music by a few sentences in the very interesting Chapter 2, "From oral to written tradition in Javanese music", in Judith Becker's study of Central Javanese gamelan (1980). This had to do with the quality of time in different cultures and periods. It stimulated my interest in this subject.

Becker (1980: 20) explains that in oral traditions the musician "is not learning pieces, but ways of realizing pieces: he is learning process, not fixed content" and eventually he

has mastered a technique of composition, based on the manipulation of formulas, which allows him to perform and compose at the same moment [...] The group performance in Java puts many restrictions on the freedom of the musician, but still the music must be re-created, not reproduced, in any given performance.

Becker asked herself what the implications are when notation is introduced in an oral musical culture. She considers notation "the most pervasive, penetrating, and ultimately the most insidious type of Western influence [that] goes largely unnoticed" (Becker 1980:11). "The introduction of notation into an oral tradition brings with it the concept of a fixed formula that is to be repeated exactly". She also notes that Asian notation systems have been mnemonic devices, being used by musicians who already knew the composition and only needed to be reminded of certain passages. What was new in Java was not so much the notation system, but "the attitude toward notation and the

my measurements not entirely equidistant, but conceptually and in musical practice treated as such (Van Zanten 1986: 100-105, 1989: 124-126).

3 Mariko Sasaki (2007) repeated in Indonesian what I, and others, had published in English many years before: the theories of Kusumadinata need to be substantially revised. For her analysis of the modal theory (laras ganda), she did not use Cook (1993), which is a serious shortcoming. Moreover, Sasaki replaced the speculative theories of Kusumadinata by other speculations about the origin of scales. Anyhow, the question about the origin or the "authenticity" of a musical scale is not very fruitful for developing new modal theories. See on "authenticity", for instance, Heins (1975: 20), Stockmann (1988) and the 2004 Yamato Declaration of UNESCO (Proceedings 2006: 146). 
reliance placed on it" (Becker 1980: 21). In my words, this means that this different attitude would lead to a change in the quality of time created by Central Javanese gamelan music.

One of the major concerns of the introduction of notation is that it may lead to less variation and even fossilization. On the other hand, Davis (1992: 111) concludes that the forceful attempts to notate and standardize music in Tunisia did not entirely succeed:

Thus while notation was originally introduced to standardise the melodic tradition, it has since been used as a creative tool for reinterpreting and redefining it; and the fluidity of interpretation characterising the oral traditions has not entirely been extinguished.

See also Hughes (1992: 45) for similar remarks about the history of a Japanese folksong.

According to my observations, the notation of music in West Java has hardly affected the essentials of the oral tradition. This is also caused by the fact that Kusumadinata's relative notation system ( $d a-m i-n a-t i-l a)$ does not reflect musical practice and is utterly confusing, ${ }^{4}$ this was already noted a long time ago by Brandts Buys (1940). Sutton (1985: 25-26) made similar remarks about the gamelan music in Java: "the variety in gamelan music appears to be little threatened by notation". He further comments that the audio recordings (at that time mainly cassette tapes) have a much stronger effect on standardization than notation. See further Barendregt and Van Zanten (2002: 101) for remarks on these "new forms of orality", and Van Zanten (forthcoming b) on the standardizing effects of keyboard synthesizers on the pitch of the VCD versions of pop songs in West Java.

Becker (1980: 11) also wrote that notation of music "presupposes a linear concept of time". I wondered why she made this remark, as it seemed obvious to me. All music unfolds along a linear time scale: several tones after each other, no matter whether you are in an oral tradition with or without music notation, or in a written tradition. Did Becker suggest that the Javanese did not have a linear concept of time before they started to notate music? Her remark triggered me to look more carefully into the anthropology of time.

In the following pages, I shall first discuss a few issues raised in the anthropology of time and place, before I shall look specifically at the different social qualities of time created in some performing arts in West Java. I shall discuss, for instance, how music is used to connect the human world to the non-human world, how "female" time is created and comment on time and place as represented in UNESCO films showing living culture.

4 See, for instance, the list in Van Zanten (1995a: 218) with different notations of a sorog tone system as used by different authors. This confusing da-mi-na-ti-la/cipher notation system contrasts with the common Javanese kepatihan cipher notation that is absolute and related to musical practice. 


\section{ANTHROPOLOGICAL STUDIES OF TIME AND SPACE}

Durkheim was the first one to point out that "collective representations of time do not passively reflect time, but actually create time as a phenomenon apprehended by sentient human beings" in 1915 (Gell 1992: 3-4). Time and space are mediated by society, and by our social practices such as making music, meetings of political parties, etcetera, we create meaningful time and space..$^{5}$ In the first chapters of his book, Gell (1992) points out, that anthropologists like Evans-Pritchard, Lévi-Strauss and Leach followed in Durkheim's footsteps, although with some changes.

According to Leach (1976: 83), during rituals intervals of sacred "timelessness" are inserted in between social, secular time. Therefore the social time seems to become discontinuous. The transition from social to ritual time and back is mostly clearly marked. Lévi-Strauss (1975: 15-16) remarks that music, like mythology, is in fact a means to deny time: the internal organization of the music causes the social time to stand still, when we listen to music. By listening to music, the listener gets into a state of immortality. In many musical genres of Southeast Asia, these ideas of timelessness, endlessness or eternity are expressed by a drone: a constant layer of sound, such as in Indian music, or with an ever again repeated melodic phrase (Maceda 1986: 45).

Adam (1997: 503) gives two reasons why anthropological theorizing about time is still in the formative stage:

First, time is implicated not only in the subject matter of anthropology but also in the lives, understandings, and methods of those who conduct the studies. Second, in spite of its omnipresence, time is curiously invisible and constitutes one of the most taken-for-granted features of our lives.

Adam goes on to remark that in dealing with "other" cultures, the real problem is that anthropologists have an "[...] unquestioned understanding of Western time; it reaches the very base from which researchers explicate the time of 'the other'". In her essay, she therefore primarily focuses on the "implicit time of the 'invisible observer'", and not on the "explicated 'other time'“(Adam 1997: 504).

Anthropologists often talk about time and space together in one model. Time and space are not separated, because different places mark different experiences, or qualities, of time. In many cultural groups, and especially in Africa, there is a clear distinction between the place of the settlement and the place of the forest (and/or the sea, such as in Indonesia). ${ }^{6}$ The forest is "regarded as a vastly rich and diverse life-sustaining resource, but it is also dangerous and life-threatening [...]" (Jedrej 2002: 548). Jedrej observed that the relationship between settlement and forest in Guinea Coast, West Africa

5 Social practices are "activities, which manifest ever-changing concepts, knowledge and skills, related, among other things, to social relations, status, methods of decision-making, conflict resolution, and collective aspirations" (Glossaire 2002).

6 See for the representation of the sea in tembang Sunda Cianjuran song texts Van Zanten (1989: 72-73). 
is also "temporal", as it changes:

- founding ancestors built houses by cutting space out in the forest;

- human beings in the settlement are sustained only by re-establishing a relationship between settlement and forest.

The relationship between forest and settlement is a metaphor of the more abstract relationship between the visible world of mortals and the invisible world of spiritual beings. Rituals are needed to communicate between the human world and the non-human world. We know that music often plays an essential role in this process of communication between the human and the non-human world, and below I shall present examples.

In the past, cultural groups were sometimes too easily classified according to whether they use a linear or a cyclical concept of time. Later anthropological research has shown that mostly there are several ways in which time may be experienced in a society. For instance, Thapar (2005: 28) remarks that in chronicles of Early India "[...] time is linear and the assumptions of cyclic time may be implicit but remain distant. Cyclic time is not denied and is present in the large reckoning. [...] Time was thought of at many levels" (Thapar 2005: 28).

Cyclical, circular, or repetitive time does not logically exclude linear sequencing. For instance, in Indonesian gamelan music, the second playing of a gong period (cycle) comes after the first playing, etcetera. Further, metaphysical and sociological arguments about time should not be confused. Ideas about re-birth and "notions of infinity" (Maceda 1986: 45) have to do with the metaphysical level. Time in music and other performing arts has to do with the social level, and it is always linear or cumulative, although it may be used to create these "notions of infinity".

Munn (1992: 101) formulated this as follows (see also Adam 1997: 511, 519):

The illusional model of time often draws on dichotomous abstractions like cycliccircular vs linear, and spatial vs temporal. [...] The circular-linear opposition has also been questioned on the basis that so-called "circular" (repetitive) time does not logically exclude "linear" sequencing because each repetition of a given "event" necessarily occurs later than previous ones. [...] The analogy between time and a circle closing back on itself misleads here. [...] These points return us to the notion of noncumulative time. [...] Varied ethnographic accounts since the 1970s give substantial evidence of the widespread view of long-term time as an incremental process, often conveyed in organic images of "continuous and progressive" growth [...], or in ancestral, creative place-to-place travel involving increasing extension from an origin place $[\ldots]$.

Hence despite the vast variety of metaphors for time and of the indicators to measure time, time generally tends to be perceived as both linear flow and as repetitive (Jedrej 2002: 548).

We may expect that in most cultural groups these different ways of experiencing time may be reflected in the ways they create time in their music and other forms of living culture. In safeguarding living culture (or intangible cultural heritage), it is important to look at how performers and audience experience the time created by music and other performing arts. The different 
social qualities of time are more relevant than the metaphysical ideas that are attached to it. The question is what living culture means to communities and not whether their ideas about the metaphysical world are "true" or not.

\section{COMMUNICATION BETWEEN HUMAN AND NON-HUMAN WORLDS}

\subsection{NTHANO STORIES IN MALAWI}

All over the world music plays a role in the communication between human beings and the non-human world. For instance, in many denominations of monotheistic religions it is felt more appropriate to address the God by "singing" than by speech. Further, Lévi-Strauss (1973: 323-324) reports that Bororo humans in South America may "talk" to plants in a "flute language" or "super-language". ${ }^{7}$ The following Malawian example also emphasizes that human speech is not powerful enough for communication between humans and the non-human world. It is taken from Malawi in Central Africa, because it is relevant for our discussion and I do not know similar examples from Indonesia or other parts of the world.

In 1971, my wife and I recorded 23 stories, told by girls attending a mission school in southern Malawi. ${ }^{8}$ Each $n$ thano story contains a song, which may be repeated several times within one story. The storyteller sings the songs, and tries to actively involve the audience by asking them to sing the chorus part. In the introduction to his book with similar stories from Zimbabwe, Tracey (1967: ix) remarks:

At important and exciting moments of a story the African teller with his small audience may break into the melodic and rhythmic discipline of a song, point against point, savouring the emotion of a moment too important for the irregular flow of prose.

This certainly also holds for the songs in Malawian $n$ thano stories.

However, in our analysis of the songs, it also became clear that the songs are systematically used when there is communication between human beings and non-human beings, like animals, plants, and the deceased. The deceased would often transform into a snake or bird, and then the human beings would sing to it. In the Malawian $n$ thano stories, animals and plants also sing to human beings. The spoken word was only used for communication between human beings (W. van Zanten and E. van Zanten 1995: 599; Van Zanten 2008a: 2-4). The summary of the story with song "The mother and the orphan"

\footnotetext{
Also, cultivated plants may "talk" to Machiguenga humans of South America in an unarticulated way or "sub-language".

A copy of these recordings with about 15 hours of (mainly) Sena music of southern Malawi, with documentation, Sena song texts and English translation, were deposited in the archives of the University of Malawi (Zomba, Malawi) and the University of Amsterdam (the Netherlands). In December 2008 a digital copy of the materials was presented to the Department of Fine and Performing Arts, Chancellor College, University of Malawi. We are very grateful to Ralph Kabwadza, then a student of Chancellor College and born in Nsanja District, southern Malawi, for his help during the recording and documentation sessions.
} 
(Mai ndi mwana wamasiye) goes as follows. ${ }^{9}$ Before a woman died, she told her youngest daughter: "My child, when I die, you must go to your elder sister; her name is Ngoza". After the death of her mother, the girl left her mother's house with a servant for the village where her elder sister was living. On their way, the servant suggests that they change their clothes, which they do. On arrival, the elder sister does not recognize her younger sister, and she is treated as a servant, while the real servant is well treated as the younger sister because she is wearing her clothes. The elder sister cooks a frog and maize porridge for her "younger sister", but the "servant" gets chicken and rice. One day the real younger sister is chasing birds from her sister's garden. She sings in distress, to chase the birds:

Original text of song in Chitonga
Swa mbalame
Amangonena
Asani ndafa ine
Unke kwa mkulu wako
Mkulu wako ndi Ngoza
[chorus: ]
Kawinga-winga gogo kawinga

Original text of song in Chitonga

Swa mbalame

Asani ndafa ine

Unke kwa mkulu wako

ginga gogo kawinga

\author{
English translation \\ Ksssht, birds! \\ She said to me: \\ When I die, \\ You must go to your elder sister. \\ Your elder sister is Ngoza
}

Chasing the birds, grandfather, chasing the birds.

The birds flew away, but another big bird came and the girl did not know it was her deceased mother. The big bird kept eating the rice. Although the girl sang and sang, it did not go away. Eventually the bird changed into her mother and she gave her daughter plenty to eat. When the girl went home, her elder sister cooked maggots and chaff for her, but the younger sister did not eat it. Eventually the elder sister discovers that her younger sister gets food from her deceased mother, who arrives at the rice field as a large bird. The servant is then punished by putting her in a large bin with boiling water.

The song of this $n$ thano story, like in all other stories we recorded, carries the communication between two different worlds that are temporally connected:

- all human beings eventually die, and move to the non-human world; the non-human world consists of deceased relatives, but also of animals and plants;

- now and then a deceased mother, plant or animal may be asked for help, when human beings are in difficulties: the relation is re-established.

9 This story was told in the Chewa language (Chichewa) and with the song in the Tonga language (Chitonga) by eleven-year old Rose Ntuwana from Blantyre. 


\subsection{CARITA PANTUN, ANGKLUNG, AND SPATIAL ORIENTATION}

The Malawian nthano stories are told in secular time, not in ritual time. The ritual time, marking the communication between the human and the nonhuman world, is created in the story, but the story itself is not told in ritual time. This is, for instance, different from the Sundanese sung epic narratives (carita pantun) that are considered to belong to the abode of the gods and are told in ritual time, of which the beginning is marked with an offering (sasajen). A recitation is usually in the context of ceremonies for occupying a new house or protecting the rice from illnesses, and for circumcisions, weddings, and the like. For instance, Enjum from Ujungberung started his recitations of the epic narrative in the 1970s and 1980s with the sung opening (rajah) as from line 19:

\begin{tabular}{|l|l|l|}
\hline & \multicolumn{1}{|c|}{ Original Sundanese } & \multicolumn{1}{c|}{ English translation } \\
\hline & {$[\ldots]$} & {$[\ldots]$} \\
\hline 19 & Ti mendi pipasinieun & From where is this story? \\
\hline 20 & Ti mana picaritaeun & From where does it come that will be told? \\
\hline 22 & Tetepna di kahiyangan & Its place is in the abode of the gods. \\
\hline 23 & Ditandéan cupu manik & Caught in a (magical) jewel-box, \\
\hline 24 & Diwadahan ku sarat tangan & $\begin{array}{l}\text { Put into a sarat tangan (magical jewel- } \\
\text { box?), }\end{array}$ \\
\hline 25 & Dituruban ku mandepun & Covered with a small cloth. \\
\hline 26 & Diteundeun di jalan gedé & Put down on the large road, \\
\hline 27 & Dibuka ku nu ngaliwat & Opened by a passer-by, \\
\hline 28 & Ku nu weruh katimuna & $\begin{array}{l}\text { By someone who is acquainted with what } \\
\text { is found, }\end{array}$ \\
\hline 29 & Ku nu terang bijaksana & $\begin{array}{l}\text { By someone who is knowledgeable and } \\
\text { wise }\end{array}$ \\
\hline 30 & Ku nu rancagé di angen & $\begin{array}{l}\text { By someone whose knowledge is many- } \\
\text { sided. }\end{array}$ \\
\hline 31 & Dibuka pating haleuar & When it is opened, there is great joy (?) \\
\hline 32 & Nu mundut dilalakonkeun & With them who asked for the performance. \\
\hline
\end{tabular}

(Van Zanten 1993: 156-157)

Time and spatial orientation may also be related. In the Baduy minority group of West Java, the male singer, when performing such epic narrative (pantun story) during a ritual, has to face a certain direction that depends on the day of performing. This position changes from day to day in a clockwise way. On the evening of Wednesday 2 April 2003, I recorded the story Paksi Keuling 
recited by Sawari in Margaluyu, outside the Baduy area of Kanekes. ${ }^{10}$ The performer asks forgiveness for "mentioning the forbidden names" (nyebut ngaran pamali), that is, the holy names of the gods and ancestors, when telling the story of Paksi Keuling.

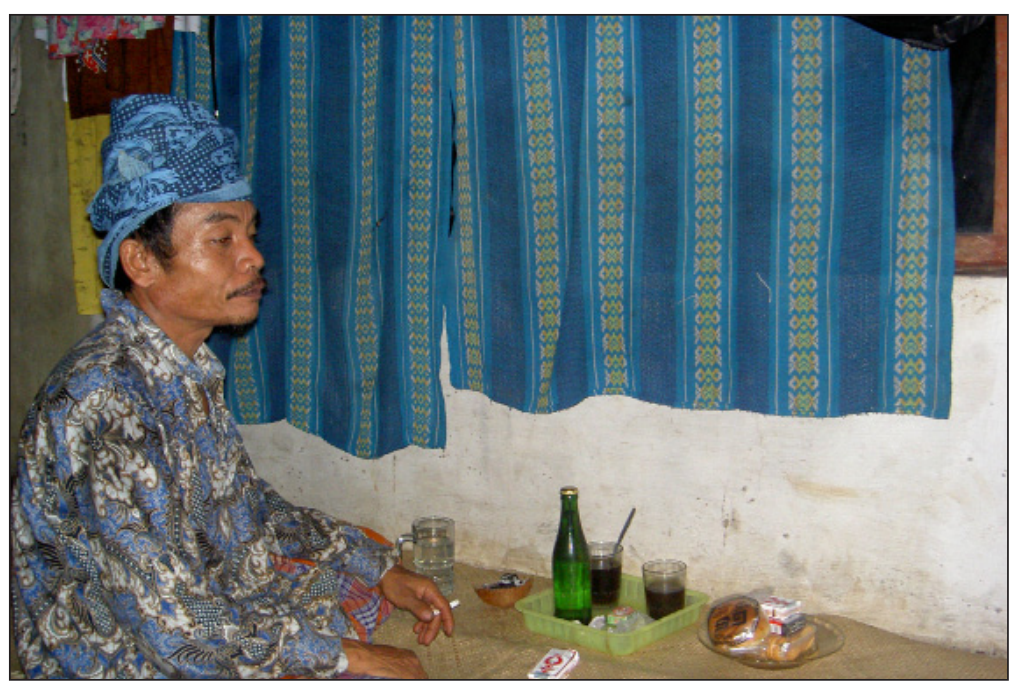

Picture 1. Sawari smoking during a short break in the recitation of the pantun story Paksi Keuling at the House of Haji Nalim in Margaluyu, Leuwi Damar. He is facing southwest, like during the recitation. On the ground, a coconut shell with burnt incense and other ingredients of the offering (Photograph by the author, 2 April 2003).

The recitation took place on Wednesday night (malam Kemis: the night starting Thursday). ${ }^{11}$ The storyteller faced the southwest direction and was not fully facing the audience in the room (see Picture 1). When sowing rice in daytime on Thursday (Kemis), Baduy also have to start at the southwest corner of the field and go around in a clockwise direction, the direction in which the mythical snake moves (gilir naga). Sawari told that the relation between the day and direction is as follows:

10 The male singer Sawari was then about sixty years old. He had been an Inner Baduy from Cikadu, before he transmigrated to the area outside Kanekes in the 1970s. Therefore he no longer belonged to the Baduy community at the time of recording. See on this complex situation further Van Zanten (2004a). On this evening Sawari did not accompany himself on a kacapi zither, which is exceptional for Baduy storytellers.

11 In many cultural groups sunset/nightfall is considered the start of a new day, but in most western countries a new day starts at midnight, and this is expressed by clock-time. In the Indonesian language both ways of time reckoning can be expressed: malam Kemis (the night starting Thursday) and Rabu malam (the night following the daytime of Wednesday). 


$\begin{array}{lll}\text { Direction } & \text { pantun story } & \text { planting of rice } \\ \text { North } & \text { Friday night } & \text { Saturday }{ }^{12} \\ \text { Northeast } & \text { Saturday night } & \text { Sunday } \\ \text { East } & \text { Sunday night } & \text { Monday } \\ \text { Southeast } & \text { Monday night } & \text { Tuesday } \\ \text { South } & \text { Tuesday night } & \text { Wednesday } \\ \text { Southwest } & \text { Wednesday night } & \text { Thursday } \\ \text { West } & \text { Thursday night } & \text { Friday } \\ \text { Northwest } & \text { not used } & \text { not used }\end{array}$

In the Baduy society, it is the agricultural rice cycle that determines different musical seasons of the year (Van Zanten 1995b: 527). The angklung ensemble consists of nine bamboo idiophones with two or three drums; each idiophone consists of three tubes in a frame that is shaken. The angklung is played in combination with singing and dancing by men. This angklung ensemble is used to mark the beginning of the planting of rice: during a ritual, the goddess of rice (Déwi Asri) is engaged to the Earth. The angklung ensemble is also used in the first three months of the planting season (most years about SeptemberNovember), and it may be played when the young rice plants are cured for illnesses. During the ceremony of engaging the goddess of rice to the earth, the angklung players walk around a basket with rice in a clockwise circle (gilir naga), that is, the "holy" direction in many parts of Asia.

Apart from the use in a ritual setting, the angklung music is also used for entertainment. When used for entertainment, the men sing sisindiran with their playing. ${ }^{13}$ A soloist will sing the main text, and a chorus answers, or a man/boy and woman/girl will alternate the singing of a verse. These texts are mainly about love. During this secular, non-ritual occasion the players, while playing, walk in a circle in an anti-clockwise direction. Hence with the Baduy the direction in which the angklung players walk marks secular (anticlockwise) or ritual time (clockwise).

In 1992, I recorded three sets of angklung (each set consisting of nine shaken idiophones) during a rice planting ritual with the Baduy of West Java (Van Zanten1995b: 532-537). Three angklung groups from different villages were involved, because it was an important occasion. The three groups played together for most of the night. The angklung sets came from three different villages and their tuning did not match very well. Generally speaking, musicians and audience clearly hear these imperfections and will not accept them. At this time for the important Baduy ritual (the engagement of the rice goddess to the earth), the communal feeling was apparently thought to be

12 Garna $(1988: 261,264)$ gives a similar scheme, except that the direction North is not used; instead, direction Northwest is used on Friday night/Saturday. Garna's scheme seems more logical.

13 A sisindiran is a poem in which an allusion (sindir) is given by a combination of words which allude to the real meaning by sound association (Van Zanten 1989: 68). 
more important than the exact matching of the tunings of the three angklung sets (Van Zanten 1997: 47-48). We could say that playing the three angklung sets together created time in which the emphasis was shifted from musical to communal qualities.

\subsection{TRANCE IN KUDA LUMPING PROCESSION}

In Ujungberung, the eastern part of Bandung, Indonesia, Sundanese boys of about six to eight years old are carried in a procession around the surrounding villages on the day before they are circumcised. The boys wear special clothes to indicate that they are "king for one day" (raja sapoe) and they may sit on horseback or on lion-shaped seats carried by four men. The horses are trained to walk on the beat of the music (kuda rénggong). A car may also be used to seat the "king for one day" in the procession (see Picture 2). Although circumcision of the boys is done according to the Islamic tradition, some of the cultural references in the procession relate to Hindu, rather than Islamic tradition: the lions refer to the Hindu king Siliwangi, for example.

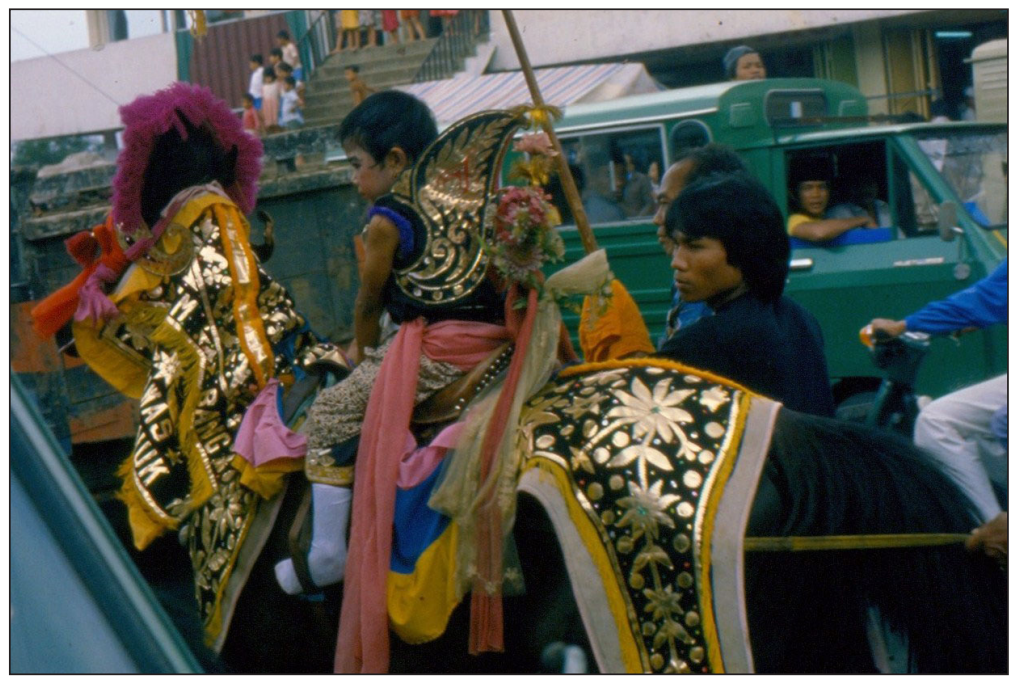

Picture 2. A boy to be circumcised the following day, a "king for one day", is carried around on horseback in a bénjang procession (Photograph by the author, Ujungberung 1981).

The boys are accompanied by a performing dance troupe (kuda lumping). The dance troupe consists of a man with a horse mask (bangbarongan) and dancers on hobbyhorses, made of leather, who are often accompanied by clowns. The dancers on a hobbyhorse may go into a trance. The leader (malim) takes him out of his trance by blowing cigarette smoke in his face, massaging his neck or sprinkling water over his face (Pictures 3 and 4). The dance troupe is accompanied by a small musical group or groups, playing a variety of instruments including drums, gongs and a shawm; some processions include a brass band (tanjidor). In 1990, one procession was observed in which the music group played on drums fitted on a bicycle, frame drums (terbang), gongs and 
an electric guitar with an amplification system.

There may be several dance and music troupes involved in the procession, and a procession does not always have the same composition of troupes. The troupes are hired by wealthy families who are having their boys circumcised and who also pay for the important ceremonial meal (sidekah, selamatan) afterwards. A few boys from poorer families may join the procession before their circumcision, and contribute to the cost by providing donations of labour or other services.

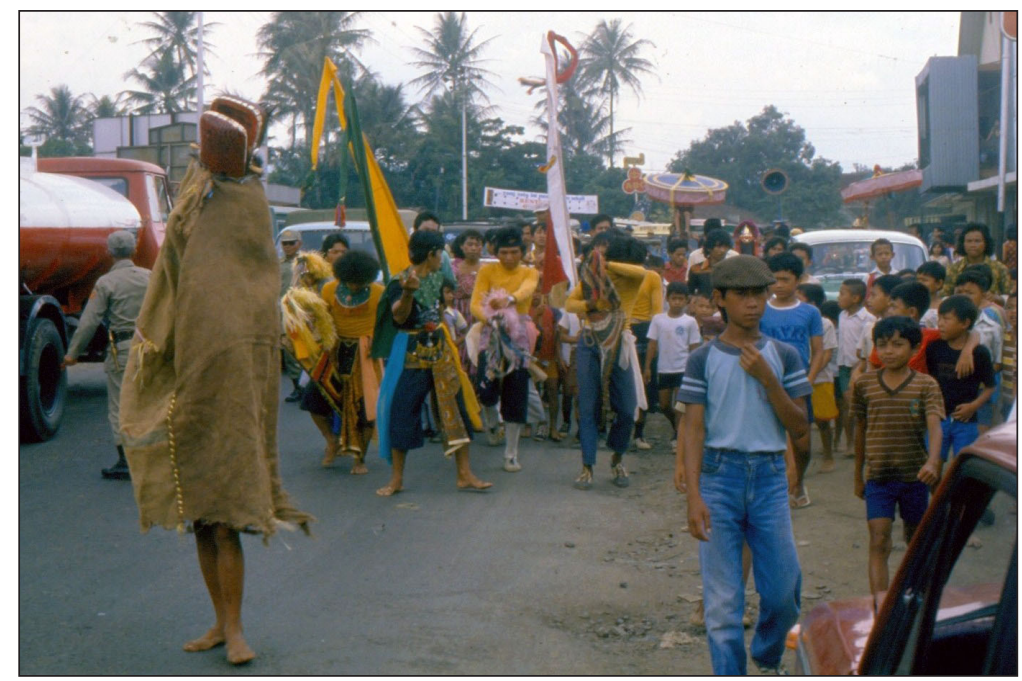

Picture 3. Bénjang procession with horse mask (bangbarongan), hobbyhorse dancers and their leader (malim) (Photograph by the author, Ujungberung 1981).

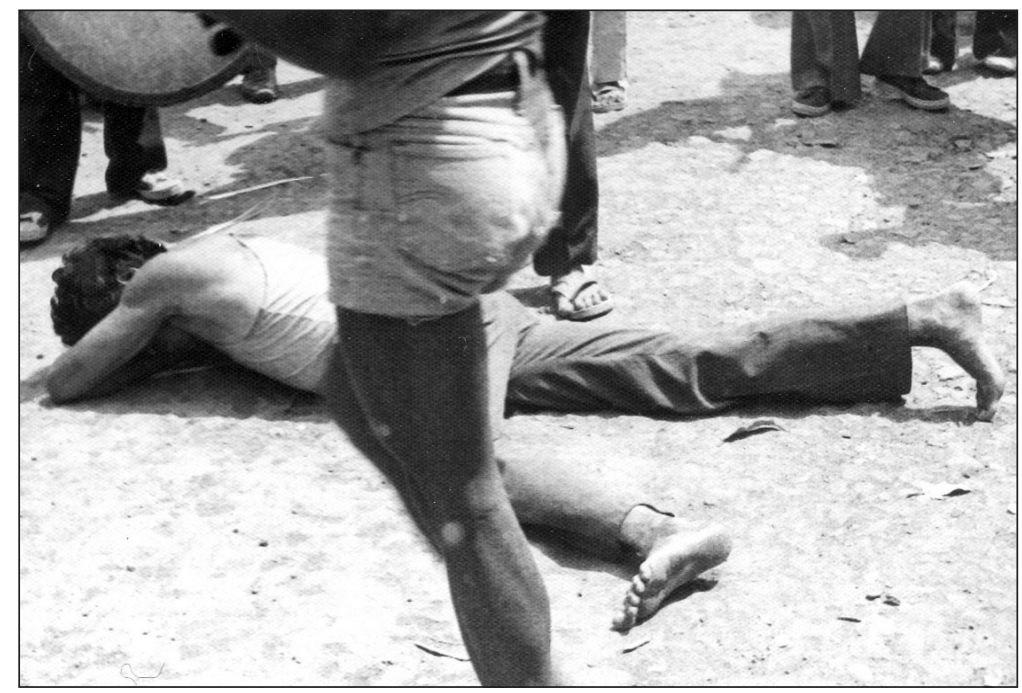

Picture 4. One of the hobbyhorse dancers is lying on the ground, recovering from his trance after a bénjang procession (Photograph by the author, Ujungberung 1981). 
Trance is an "unusual" condition of a human being. Dance and trance support the communication between the human and the non-human world; it is mostly part of the complex consisting of religion/ritual and/or the health system. ${ }^{14}$ In possession trance, a god, ancestral spirits, or witches, etcetera, take possession of the human body and this is manifested by the behaviour of the possessed person. The trance is a manifestation of the temporal connection between the human and the non-human world.

\section{FEMALE TIME IN TEMBANG SUNDA CIANJURAN}

Tembang Sunda Cianjuran is solo singing with the accompaniment of two zithers (kacapi indung and kacapi rincik) and a bamboo flute (suling); occasionally a twostringed spike fiddle (rebab) or violin is used instead of the bamboo flute. All instruments are played by men, and the singers are mostly women, although men may also sing. The most important classification of the songs is in mamaos, sung in rubato style (that is, without a strict beat) and the metric kawih songs. The songs are sung in sets of 2,3, or 4 songs; the first songs of each set are always rubato songs, and the set is concluded with one metric song.

The metric songs have a structure of repeated gong phrases; mostly each gong phrase lasts eight "beats" with a speed of $44-60$ per minute. ${ }^{15}$ In contrast to this repetitive way of structuring the music, the rubato music is structured along a non-repetitive, more strictly "linear" concept. In the following table, the rubato songs are compared to the metric songs.

\begin{tabular}{|l|l|l|}
\hline \multicolumn{3}{|l|}{ Tembang Sunda Cianjuran songs compared } \\
\hline Characteristics & Rubato songs (mamaos) & Metric songs (kawih) \\
\hline gender & sung by men and women & $\begin{array}{l}\text { sung by women only } \\
\text { ("female time") until the } \\
\text { 1990s }\end{array}$ \\
\hline technicalities of singing & $\begin{array}{l}\text { tense way of singing; } \\
\text { considered to be more } \\
\text { difficult to perform }\end{array}$ & $\begin{array}{l}\text { more relaxed way of } \\
\text { singing; considered to be } \\
\text { easier to perform }\end{array}$ \\
\hline $\begin{array}{l}\text { prestige and musical } \\
\text { appreciation }\end{array}$ & $\begin{array}{l}\text { relatively more } \\
\text { prestigious, but musically } \\
\text { less appreciated by most } \\
\text { listeners }\end{array}$ & $\begin{array}{l}\text { relatively less } \\
\text { prestigious, but } \\
\text { musically more } \\
\text { appreciated by most } \\
\text { listeners }\end{array}$ \\
\hline contents of song texts & $\begin{array}{l}\text { more about the glorious } \\
\text { past of Hindu kingdoms, } \\
\text { and nature }\end{array}$ & $\begin{array}{l}\text { more about human } \\
\text { relations, such as love, in } \\
\text { present and future }\end{array}$ \\
\hline
\end{tabular}

14 See further Rouget (1985); this book is still a standard introduction to trance and music.

15 The gong phrases in a song may also last 4 beats (in one wilet songs) or 16 beats (in four wilet songs).

16 In the 1970s the names of these metric songs were often not mentioned on commercial cassette tapes. 


\begin{tabular}{|l|l|l|}
\hline \multicolumn{2}{|l|}{ Tembang Sunda Cianjuran songs compared } \\
\hline Characteristics & Rubato songs (mamaos) & Metric songs (kawih) \\
\hline time arrangement in song & $\begin{array}{l}\text { non-repetitive, "linear" } \\
\text { time }\end{array}$ & repeated gong cycles \\
\hline $\begin{array}{l}\text { temporal structure } \\
\text { created by large zither }\end{array}$ & $\begin{array}{l}\text { relative "chaos"; in most } \\
\text { songs cascades of notes } \\
\text { ending on core notes are } \\
\text { played; only some songs } \\
\text { are accompanied by } \\
\text { repeated regular patterns } \\
\text { (ostinato) }\end{array}$ & $\begin{array}{l}\text { relative "order" by strict } \\
\text { beat; large zither plays } \\
\text { syncopated bass part } \\
\text { to accentuate the strict } \\
\text { tempora lorder }\end{array}$ \\
\hline
\end{tabular}

From this scheme, it is clear that in the tembang Sunda Cianjuran genre "time" is created in a variety of ways: there are many factors contributing to the experience of time. Elsewhere I have remarked that in Sundanese thought music represents female aspects of communication (Van Zanten 1989: 110111, 192, 1994: 86-87). For instance, the zither is compared to the rice goddess Déwi Asri, the sound of the two-string spiked lute is compared to a woman's voice, and the sound of the bamboo flute is plaintive and evokes emotional feelings, considered to be female characteristics. Further, the Sundanese tend to describe themselves as cheerful and good-humoured in daily life. Feelings of sadness, and generally speaking strong emotions, are mainly communicated via the performing arts, which is not to say that there is no humour in the performing arts (Williams 1993). One may say that the Sundanese performing arts and tembang Sunda Cianjuran particularly, create time with many female characteristics. In a similar way, Williams (1998) describes the Sundanese performing stage as "neutral" territory, where women are the "hosts", and men (the instrumentalists, male singers) are their "guests".

Within tembang Sunda Cianjuran the metric songs show more female aspects than the rubato songs. First of all, the metric songs were - until the 1990s - exclusively performed by women. There was one standard exception, confirming the rule. In this particular metric song, Budak Ceurik, the instrumental interlude may be used by a man to sing (this singing is called alok). ${ }^{17}$ This is a breach of "how it should be done", a musical disturbance of the social order. The text sung by the male vocalist-intruder is always about the bamboo flute that is "out of tune," and the singer who is "confused," that is, a metaphor for being in love with someone else than his own wife, possibly the female singer:
Kuma suling $(2 x)$
How about the flute?
Suling téh ngan silung baé
The flute is just out of tune

17 The remark in Van Zanten (1989: 243) on the song Budak Ceurik in Example 3 of the accompanying cassette tape is therefore not correct: the alok singing by Gatot Sutardi was common and not for lightening the task of the old female singer Cicih. 

Kuma kuring (2x)
What about me?
Kuring téh ngan bingung baé
I am just confused

A flute and any other instrument that is out of tune is a metaphor for disturbed social relations and meaningful to Sundanese audiences, also in other genres. In 1990 I filmed a gathering (panglawungan) of tembang Sunda Cianjuran singers, musicians and connoisseurs at the TV studio in Bandung. When the song Budak Ceurik was sung (by Ottih Rostoyati) a male organizer of the event broke into the song as described above. The female Master of Ceremonies smiled and pointed her finger at him, signalling that he was "naughty" (Picture 5). There was laughter. See further Van Zanten (1989: 105, 110-111, 194, 1994: 87-90).

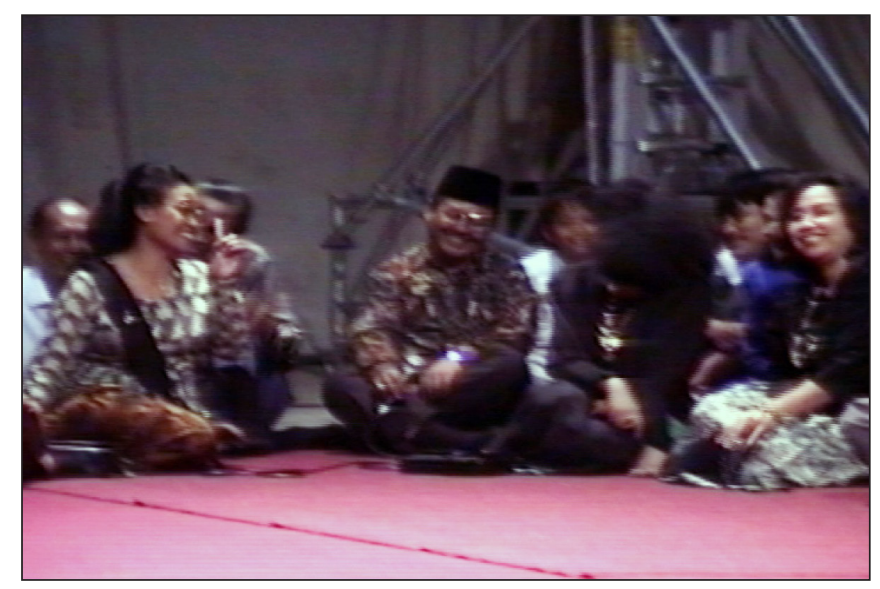

Picture 5. The Master of Ceremonies (left) signs with her left finger that the male singer with microphone in the centre is "naughty", because he intruded in the "female time" of the song Budak Ceurik, TVRI studio Bandung (Photograph by the author, 21 October 1990). ${ }^{18}$

The metric songs in particular are dominated by women, who sing about human relations and love. The role of men and women performers should be seen as a process of negotiation between men and women during the twentieth century. For instance, in the 1990s men singing the metric songs, and women playing the instruments were no longer exceptional. ${ }^{19}$ During the period after 1950, the Indonesian government successfully stimulated the participation of women in the performing arts. In West Java women started to play instruments and instrumental groups of kacapi-suling and gamelan degung sometimes consisted of only women, with the exception of the drum (kendang)

18 The quality of Picture 5 is the same as the provided original. [Editor.]

19 In 1996 the Daya Mahasiswa Sunda (Sundanese Students' Organization, DAMAS) organized a singing contest in which metric songs for the first (and only) time also became compulsory for male singers. 
and bamboo flute player (suling). The late Euis Komariah (1946-2011) describes that in 1967 she performed with a women's gamelan degung group in Jakarta and then the flute player was also a woman, namely the famous Siti Rokayah (Amalia 2010: 30-31; see also Van Zanten 2008b: 46-49). As compared to the beginning of the twentieth century, these days there is much more dominance of women performers, a slower tempo and more ornamentation in tembang Sunda Cianjuran songs (Van Zanten 1989: 180).

\section{TIME AND SAFEGUARDING LIVING CULTURE}

The 2003 UNESCO Convention for the safeguarding of the intangible cultural heritage (UNESCO 2003) offers an important podium for discussing cultural policies: why, what and how should we safeguard? This convention is concerned with intangible cultural heritage (or living culture) that is manifested in five domains, including oral traditions and expressions, performing arts, social practices, and knowledge and practices concerning nature and the universe. Further, the 2003 Convention is about intangible cultural heritage "that communities, groups and, in some cases, individuals recognize as part of their cultural heritage" and the state parties should carry out the safeguarding "with the participation of communities, groups and relevant nongovernmental organizations". Hence, although the parties of the convention are states, the text of the convention clearly mentions the importance of involvement of (cultural) communities in safeguarding processes. ${ }^{20}$

In the earlier 1972 UNESCO Convention concerning the protection of the world cultural and natural heritage "cultural heritage" included only tangible objects and was defined as: monuments, buildings and sites of "outstanding universal value from the point of view of history, art or science" (UNESCO 1972: article 1). The 2003 Convention does not use the concept of "outstanding universal value", because this includes a problematic value judgment; for visibility purposes, it has a Representative list of the intangible cultural heritage of humanity. The terminology of the 2003 Convention is much more up-todate with the present state of affairs in the social sciences than in the 1972 Convention (Van Zanten 2004b).

As the 2003 Convention has been operating for a few years we may ask how it has been implemented so far. The complexity of living culture with an emphasis on processes rather than objects, forces us to pay much attention to the methodology of safeguarding. Has this been successful? Researchers can judge for themselves by visiting the Internet site of the Intangible Cultural Heritage section of UNESCO (http://www.unesco.org/culture/ich/), because there is a wealth of information to be found.

20 A definition of "community" is: "People who share a self-ascribed sense of connectedness. This may be manifested, for example, in a feeling of identity or in common behaviour, as well as in activities and territory. Individuals can belong to more than one community". A definition of "cultural community" is "A community that distinguishes itself from other communities by its own culture or cultural design, or by a variant of the generic culture. Among other possible extensions, a nation can be a cultural community" (Glossaire 2002). 
In this essay on the social qualities of time, I am particularly interested in knowing how much the different State Parties, including Indonesia, have been respecting the "flow of time" in the different communities of which items were put on one of the international lists. Apart from the Representative List there is the provision for the Urgent Safeguarding List and the List of Best Practices (UNESCO 2003: articles 16-18). How serious this cultural flow of time was taken can be judged, for instance, from the 10-minute video films that accompany most items on these lists. ${ }^{21}$

Films about living culture may be used to raise awareness of cultural diversity and respect for, and enhancement of living culture. This will only be effective, if we respect the cultural flow of time, that is, the social qualities of time as experienced by the participants of the cultural group concerned. A correct representation of the cultural flow of time, or the "rhythm" of the cultural group, has not always been successful in the film examples on the UNESCO site. The criterion should be whether the cultural group itself is satisfied with this film representation. I wonder how many State Parties have really tried to find out whether this was the case, when they made the film excerpts and before sending this to UNESCO for a nomination on one of the international lists. ${ }^{22}$

\subsection{ANGKLUNG ON REPRESENTATIVE LIST 2010}

Angklung was proposed by the Indonesian government and inscribed on the Representative List in 2010. In the film on the UNESCO site, the emphasis is very much on the diatonic angklung as practiced in the Saung Angklung Udjo. ${ }^{23}$ This is a group of well-known performers and makers of angklung instruments in Bandung that regularly performs for Indonesian and foreign tourists. In this UNESCO film, the "Baduy" angklung group was not filmed in their village Kanekes, but presumably in Rangkasbitung. The men of this "Baduy" angklung group are wearing slippers, sandals and long trousers. However, Baduy men are not allowed to wear shoes, slippers, sandals or long trousers (Van Zanten 1995b: 519, 2004a: 126). Hence, it seems very unlikely that the filmed group (that appears also on the first slide) are Baduy people.

During my fieldwork in 1993 and 2003, I had noted that the local government in Rangkasbitung collected Baduy instruments and trained nonBaduy people to play these instruments in Rangkasbitung, that is, in a region where no Baduy live. This was considered the best way of safeguarding Baduy living culture according to a local official from Rangkasbitung in 1993 (Van Zanten 2004a: 143). It seems that what I had noted in 1993 and 2003 was still being continued in 2009-2010. Moreover, in the UNESCO film the pictures

21 See http://www.unesco.org/culture/ich/index.php?lg=en\&pg=00011.

22 Most films are necessarily greatly reducing social time: showing in a short time what actually happens over many days, months or even years. A "culturally correct" reduction of social time is a complicated process.

23 See http://www.unesco.org/culture/ich/index.php?lg=en\&pg=00011\&RL=00393 \#video. 
of men planting rice in wet rice fields (sawah), just before the Baduy angklung is shown (minutes 3:37-4:04), suggest a wrong association, as the Baduy only use dry rice fields (huma). It seems that with this nomination for the Representative List the Indonesian government did not "endeavour to ensure the widest possible participation" of the Baduy. The Baduy have apparently not been involved in this part of the nomination process. However, this is a very important condition according to article 15 of the 2003 Convention. ${ }^{24}$

The Indonesian government did emphasize possible economic profits and also tried to counteract the property claims by neighbouring Malaysia on items of living culture occurring in both countries, including angklung. On 8 August 2008 the Indonesian Minister for Cooperation and Small and Medium-sized Businesses, Suryadharma Ali, remarked: “[...] just yesterday I asked the Saung Angklung Udjo and it appeared that their product has not yet a patent. However, it seems that many small and medium-sized businesses have products of quality and originality" (Pikiran Rakyat 2008). On 14 October 2008, the head of the section on Intellectual Property Rights of the Ministry of Justice, Arif Syamsudin, said: "Angklung could become a product for individual and communal intellectual property rights" (Tempo Interaktif 2008). Let us hope that the Indonesian government will not over-commercialize angklung, something that has been warned against several times in the context of this 2003 Convention.

\subsection{TANGO ON REPRESENTATIVE LIST 2009}

The tango film (Argentina and Uruguay, 2009) on the Representative List is much more problematic than the Indonesian angklung film. In the tango film we see much of the traffic in Buenos Aires, but what about the community involved in tango, what does tango mean to them, etcetera? The used technique of moving film shots of people's faces on the beat of the music (the beat lasts about half a second) is a trick that ruins the rhythm of the culture, or the flow of tango time. Why, for instance, did we not see longer shots of the dance steps instead? This film fails "to ensure better [...] awareness of its [tango's] significance, and to encourage dialogue which respects cultural diversity" (UNESCO 2003: article 16) and it comes close to a commercial video clip of pop music.

This tango film seems to be the product of an artist, who presented his/ her own vision on tango and was not interested in whether this was a proper representation of the way the community experiences tango. This film has many short shots that last only 1-3 seconds and this comes close to the setup of video clips used when promoting pop music: it is not important to see properly what happens, but it is the visual impressions that count. No problem if an artist makes such film, but there are big problems if such film

24 "Within the framework of its safeguarding activities of the intangible cultural heritage, each State Party shall endeavour to ensure the widest possible participation of communities, groups and, where appropriate, individuals that create, maintain and transmit such heritage, and to involve them actively in its management" (UNESCO 2003: article 15). 
is used for raising awareness and encouraging dialogue that respects cultural diversity. Then it is not in the first place the view of an artist that counts, but the usefulness of such film in the inter-cultural dialogue, that is, its ability to bring across what tango means to the different communities concerned.

\subsection{CLIPS FOR POP MUSIC AND UNESCO FILMS}

In Indonesian performing arts "the audience quite often participates in the performance: the borderline between audience and performers is not rigidly defined. Music is a background against which all kinds of social interaction takes place" (Barendregt and Van Zanten 2002: 86). Because of the music recordings in several forms (such as cassette tapes, VCDs, Internet) music no longer necessitates a sharing of time and place by performer and public. Recordings produced in studios, without an audience, have re-aligned how people conceive of music and therefore of time. Much popular music, but also the instrumental Sundanese kacapi-suling music, is almost entirely a product of the recording studios and live performances are rare.

Barendregt and Van Zanten (2002: 89-95) describe the visual aspects of pop music VCDs in Indonesia, both national and regional, in relation to the text of the songs. Often the images have little to do with the sung text. This is especially the case for the pirated VCDs: texts of love songs may appear together with "pictures of insects, fish and African landscapes with lions, giraffes, etcetera, and presumably North American snow landscapes with buffalos, bears and eagles" (Barendregt and Van Zanten 2002: 92). This also holds for VCDs with pop music in other parts of the world: the images are not always tied to the text according to the principle of "unity of time and place" in live performances. In video clips with pop music the aim is rather to create impressions of images than to let us see carefully what is going on and therefore the unity of time and place is no longer very important.

This is different for UNESCO films that aim at encouraging "dialogue which respects cultural diversity". In that case, the unity of time and place is important, because we have to look at living culture that is meaningful to a particular cultural community, as it is explicitly mentioned in the 2003 Convention. It is then important to understand why things are meaningful to community members and this requires an anthropological approach to the filming. That is also not simple, because communities speak with many voices.

In strategies for safeguarding living culture the factor time is very much involved, but also often "curiously invisible" and "taken-for-granted" (Adam 1997: 503). Here I have only addressed the issue of representing the "correct" flow of time in UNESCO films that are meant to be used for a dialogue which respects cultural diversity. Several scholars have raised more fundamental questions about time and heritage interventions. For instance, KirschenblattGimblatt (2004:59) remarked that "heritage interventions attempt to slow the rate of change". This may especially be true when the rate of change is for a great deal determined by forces outside the cultural environment concerned. "The control of time is not just a strategy of interaction; it is also a medium of 
hierarchic power and governance" (Munn 1992: 109). Slowing down the rate of change may sometimes be good practice, but not necessarily in all situations.

\section{CONCLUSION}

Anthropological studies have shown that most cultural communities tend to experience and perceive time in several different ways. These different ways of experiencing time are reflected in the performing arts that are also used to create a variety of social qualities of time. I have discussed this for a few cases in West Java and one from Malawi. I also argued that for safeguarding living culture it is more relevant to look at the different social qualities of time (how do the performers and the audience experience the time created by music?) than at the metaphysical qualities attached to it.

In Section 6 I argued that in strategies for safeguarding living culture the factor time is very much involved, but also often "curiously invisible" and taken-for-granted. Many films on the Internet that are used by UNESCO for the visibility of living culture are useful for the general public. However, regularly these films fall short of representing time and place properly. I have given two examples of items inscribed on the Representative List: angklung (Indonesia, 2010) and tango (Argentina and Uruguay, 2009).

Scholars and governments should start a thorough analysis of these films and other materials for the three international lists of the 2003 UNESCO convention in order to get a clearer view on what the approaches to safeguarding living culture could and should be.

\section{REFERENCES}

Adam, Barbara. 1997. "Perceptions of time", in: Tim Ingold (ed.), Companian encyclopedia of anthropology, pp. 503-526. London/New York: Routledge. [Paperback issue; first print 1994.]

Amalia, Aan. 2010. Daweung tineung Euis Komariah; Sebuah biografi. Bandung: Jugala.

Barendregt, Bart and Wim van Zanten. 2002. "Popular music in Indonesia since 1998, in particular fusion, Indie and Islamic music on video compact discs and the internet", Yearbook for Traditional Music 34: 67-113.

Becker, Judith. 1980. Traditional music in modern Java; Gamelan in a changing society. Honolulu: University Press of Hawaii.

Brandts Buys, J. S. 1940. "Het gewone Javaansche tooncijfer schrift (het Salasche-Kepatihanschrift)", Djawa 20: 87-106, 145-167.

Cook, Simon. 1993. "Parallel versions of tembang Sunda melodies", in: Wim van Zanten (ed.), Oideion; The performing arts world-wide, pp. 55-84. Leiden: Research School Centre of Non-Western Studies, Leiden University.

Davis, Ruth. 1992. "The effects of notation on performance practice in Tunisian art music", The World of Music 34(1): 85-114.

Garna, Yudistira Kartiwan. 1988. Tangtu telu jaro tujuh; Kajian structural masyarakat Baduy di Banten Selatan, Jawa Barat, Indonesia. PhD thesis, Universiti Kebangsaan Malaysia, Bangi, Malaysia. 
Gell, Alfred. 1992. The anthropology of time; Cultural constructions of temporal maps and images. Oxford/Providence: Berg.

Glossaire. 2002. Glossaire patrimoine culturel immatériel/Glossary intangible cultural heritage. Préparé par une réunion internationale d'experts à l'UNESCO, 1012 juin 2002/ prepared by an international meeting of experts at UNESCO, 10-12 June 2002. Réalisé sous la direction scientifique/edited by Wim van Zanten. The Hague/La Haye: Netherlands National Commission for UNESCO/Commission nationale néerlandaise pour l'UNESCO, August 2002/août 2002, 17+iii pp. [Http://www.unesco.org/culture/ich/doc/ src/00265.pdf, last accessed 31-1-2012.]

Heins, Ernst L. 1975. “Kroncong and Tanjidor - Two cases of urban folk music in Jakarta", Asian Music 7(I): 20-32.

Hughes, David. 1992. "'Esashi Oiwake' and the beginnings of modern Japanese folk song", The World of Music 34(1): 35-56.

Jedrej, M.C. 2002. "Time and space", in: Alan Barnard and Jonathan Spencer, Encyclopedia of Social and Cultural Anthropology, pp. 547-550. London/ New York: Routledge.

Kirschenblatt-Gimblatt, Barbara. 2004. "Intangible heritage as metacultural production", Museum International 221-222: 52-65.

Leach, Edmund. 1976. Culture and communication; The logic by which symbols are connected. Cambridge: Cambridge University Press.

Lévi-Strauss, Claude. 1973. From honey to ashes. New York: Harper and Row. [Translated from the original French edition Du miel au cendres (1966) by John and Doreen Weightman.]

Lévi-Strauss, Claude. 1975. The raw and the cooked. New York: Harper and Row. [Translated from the original French edition Le cru et le cuit (1964) by John and Doreen Weightman.]

Maceda, José. 1986. "A concept of time in a music of Southeast Asia (A preliminary account)", Ethnomusicology 30: 11-53.

Munn, Nancy D. 1992. "The cultural anthropology of time; A critical essay", Annual Review of Anthropology 21: 93-123.

Pikiran Rakyat. 2008. "Produk UKM yang dipatenkan masih sedikit", Pikiran Rakyat, 8 August 2008 [Newspaper; http://www.pikiran-rakyat.com/ index.php?mib=news.detail\&id=26865), accessed 13 February 2009.]

Proceedings. 2006. Proceedings International Conference on the Safeguarding of Tangible and Intangible Cultural Heritage: Towards an Integrated Approach. Nara, Japan, 20-23 October 2004. Paris: UNESCO. [Http:/ / unesdoc.unesco. org/images/0014/ 001470/147097M.pdf, last accessed 31-1-2012.]

Rouget, Gilbert. 1985. Music and trance; A theory of the relations between music and possession. Chicago/London: University of Chicago Press. [Original French edition in 1980.]

Sasaki, Mariko. 2007. Laras pada karawitan Sunda. Bandung: P4ST UPI.

Stockmann, Erich. 1988. "The International Folk Music Council/International Council for Traditional Music - forty years", Yearbook for Traditional Music 20: 1-18. 
Sutton, R. Anderson. 1985. "Commercial cassette recordings of traditional music in Java; Implications for performers and scholars", The World of Music 27(3): 23-45.

Tempo Interaktif. 2008. "Angklung berpeluang mendapat hak kekayaan intelektual", Tempo Interaktif, 15 October 2008. [Newspaper article by Rana Akbari Fitriawan; http://www.tempointeraktif.com/hg/ nasional/2008/10/15/brk,20081015-140250,id.html, last accessed 31-12012.]

Tenzer, Michael. 2011. "Generalized representations of musical time and periodic structures", Ethnomusicology 55: 369-386.

Thapar, Romila. 2005. "Cyclic and linear time in early India", Museum International 227: 19-31.

Tracey, Hugh. 1967. The lion on the path and other African stories. London: Routledge and Kegan Paul.

UNESCO. 1972. Convention concerning the protection of the world cultural and natural heritage. [16 November 1972.] Paris: UNESCO. [Http:/ / whc.unesco. org/archive/convention-en.pdf, last accessed 31-1-2012.]

UNESCO. 2003. Convention for the safeguarding of the intangible cultural heritage. [17 October 2003.] Paris: UNESCO. [Http:/ / www.unesco.org/culture/ich /index.php?lg=en\&pg=00006, last accessed 31-1-2012.]

Williams, Sean. 1993. "'Our laughter balances our tears'; Humor in Sundanese arts", Balungan 5(2): 11-14.

Williams, Sean. 1998. "Constructing gender in Sundanese music", Yearbook for Traditional Music 30: 74-84.

Zanten, Wim van. 1986. "The tone material of the kacapi in Tembang Sunda in West Java", Ethnomusicology 30: 84-112.

Zanten, Wim van. 1989. Sundanese music in the Cianjuran style; Anthropological and musicological aspects of Tembang Sunda. [With 90 minutes cassette tape.] Dordrecht/ Providence-USA: Foris.

Zanten, Wim van. 1993. “Sung epic narrative and lyrical songs; Carita pantun and tembang Sunda", in: Ben Arps (ed.): Performance in Java and Bali; Studies of narrative, theatre, music and dance, pp. 144-161. London: School of Oriental and African Studies.

Zanten, Wim van. 1994. "L'esthétique musicale de Sunda (Java-Ouest)", Cahiers de Musiques Traditionelles 7: 75-93.

Zanten, Wim van. 1995a. "Notation of music; Theory and practice in West Java", in: Wim van Zanten and Marjolijn van Roon (eds), Oideion; The performing arts world-wide 2, pp. 209-233. Leiden: Research School Centre of Non-Western Studies, Leiden University.

Zanten, Wim van. 1995b. "Aspects of Baduy music in its sociocultural context, with special reference to singing and angklung", Bijdragen tot de Taal-, Land-en Volkenkunde 151: 516-544.

Zanten, Wim van. 1997. "Inner and outer voices; Hearing and listening in West Java", The World of Music 39(2): 41-49.

Zanten, Wim van. 2004a. "Les tentations des ascètes; Patrimoine culturel immatériel des Baduydans le Banten du sud (Indonésie)", in: Jean 
Duvignaud and Chérif Chaznadar (eds), Le patrimoine culturel immatériel; Les enjeux, les problématiques, les pratiques, pp. 124-150. Paris: Babel/ Maison des Cultures du Monde.

Zanten, Wim van. 2004b. "Constructing new terminology for intangible cultural heritage", Museum International 221-222: 36-44.

Zanten, Wim van. 2008a. "Audiovisual documentation and its role in the transmission of knowledge", presentation, Third International Memory of the World Conference Communities and memories; A global perspective, National Library of Australia, Canberra, 19-22 February. [Http:/ /www. unesco.org/new/fileadmin/MULTIMEDIA/HQ/CI/CI/pdf/mow / mow_3rd_international_conference_wim_van_zanten_en.pdf, last accessed 31-1-2012.]

Zanten, Wim van. 2008b. "The marriage relationship between player and Kacapi zither in West Java", Ethnomusicology Forum 17(1): 41-65.

Zanten, Wim van. (Forthcoming a)."Encounters in the context of inspiring Sundanese music and problematic theories", in: Bart Barendregt and Els Bogaerts (eds), Indonesian-Dutch musical encounters. Leiden: KITLV Press.

Zanten, Wim van. (Forthcoming b). "Musical aspects of popular music and 'pop Sunda' in West Java", in: Bart Barendregt and Peter Keppy (eds), Sonic modernities. Leiden: KITLV Press.

Zanten, Wim van and Ellen van Zanten. 1995. "De kracht van muziek in Malawische verhalen", in: Connie Baak, Mary Bakker, Dick van der Meij (eds), Tales from a concave world; Liber amicorum Bert Voorhoeve, pp. 586601. Leiden: Projects Division, Department of Languages and Cultures of South-East Asia and Oceania, Leiden University. 